\title{
Modelling the agricultural and environmental consequences of non-uniform irrigation on a maize crop. 2. Nitrogen balance
}

\author{
François LAFOLIE ${ }^{\mathrm{a}}$, Bruno MARY ${ }^{\mathrm{b}}$, Laurent BRUCKLER $^{\mathrm{a} *}$, Stéphane RUY $^{\mathrm{a}}$ \\ ${ }^{a}$ Unité de Science du Sol d'Avignon, INRA, Domaine St Paul, Site Agroparc, 84914 Avignon Cedex 9, France \\ ${ }^{\mathrm{b}}$ Unité d'Agronomie de Laon-Péronne, INRA, rue Fernand Christ, 02007 Laon Cedex, France
}

(Received 26 November 1999; revised 19 May 2000; accepted 31 May 2000)

\begin{abstract}
Irrigation non-uniformity is a key factor in reducing water and N efficiency and increasing N leaching. This study simulates the impact of non-uniform irrigation on crop growth and associated nitrogen fluxes. Simulations were applied to a travelling gun irrigation system on a maize crop over a 21-year period. Cropping and intercropping periods were analysed for two fertilisation rates $\left(180\right.$ and $\left.280 \mathrm{~kg} \mathrm{~N} \cdot \mathrm{ha}^{-1}\right)$. The spatial coefficients of variations over a period of 21 years were below 37, 8, 25 and 34\%, for $\mathrm{N}$ uptake, mineralised $\mathrm{N}$, inorganic $\mathrm{N}$ left in the soil at harvest and leached $\mathrm{N}$, respectively. Simulations with or without reinitialization every year of inorganic $\mathrm{N}$ and water content at sowing gave similar results, except in specific years. Differences between high and low fertilisation treatments showed up especially for leaching. Other irrigation and fertilisation strategies should be further analysed to provide more general conclusions.
\end{abstract}

irrigation / non-uniformity / nitrogen balance / modelling / maize

Résumé - Modélisation des conséquences agronomiques et environnementales d'une irrigation non uniforme sur une culture de maïs. I. Bilan azoté. L'hétérogénéité de l'irrigation est un facteur important de réduction de l'efficience de l'eau et de l'azote, et d'augmentation du lessivage. Ce travail simule l'impact de l'hétérogéneité de l'irrigation sur la croissance et les flux azotés d'une culture de maïs irriguée au canon. L'analyse porte sur 21 ans et sépare les périodes de culture et d'interculture. Deux niveaux de fertilisation sont analysés (180 and $280 \mathrm{~kg} \mathrm{~N} \cdot \mathrm{ha}^{-1}$ ). Les coefficients de variation spatiaux sur les 21 années sont inférieurs à $37 \%, 8 \%, 25 \%$, et 34\%, pour l'azote absorbé, l'azote minéralisé, le reliquat azoté à la récolte, et l'azote lixivié. La réinitialisation ou non du stock d'eau et d'azote au semis d'une année à l'autre a peu d'effets, sauf pour 2 années particulières. Des différences existent entre les 2 niveaux de fertilisation, notamment pour l'azote lessivé. D'autres stratégies d'irrigation et de fertilisation devraient être analysées pour tirer des conclusions générales.

irrigation / hétérogénéité / bilan d'azote / modèle / maïs

Communicated by Gérard Guyot (Avignon, France)

* Correspondence and reprints

Laurent.Bruckler@avignon.inra.fr 


\section{Introduction}

The use of water and $\mathrm{N}$ fertilisers in agriculture are environmentally sensitive issues $[14,15]$, especially for intensive cropping systems with high inputs of irrigation water and fertilisation. Improved management practices for water and $\mathrm{N}$ fertilisers in agriculture offer a possible means of limiting environmental contamination by nitrate [23]. Control of water depth, timing and distribution uniformity are key factors for more efficient use of water and fertilisers by crops, and for limiting percolation below the root zone $[2,9,16]$. Non-uniform water application remains a common characteristic of irrigation equipment [1,20,21], and its impact on crop yield and water balance has been documented. The impact of non-uniform irrigation on the water budget has been analysed in detail [7], but the link between water and nitrogen has rarely been described, although it is essential for optimising plant growth and minimising environmental damage $[6,25]$. Indeed, water and $\mathrm{N}$ fluxes interact strongly in soil-plant processes such as crop uptake, organic matter mineralization, denitrification and leaching $[12,23]$. Thus, it is essential to take into account water and nitrogen relationships when analysing the impact of irrigation non-uniformity on yield and environment, particularly for a non-point source pollutant like nitrate. Models developed for this purpose, must take into account agricultural practices like sowing and harvesting dates, organic matter and fertilisation management, and must give a realistic representation of physical and biological processes in the soil-plant system $[5,25]$. Such models have been used to simulate the impact of irrigation strategies on water and nitrogen budgets $[14,15]$, to simulate the combined effects of irrigation level and uniformity, and $\mathrm{N}$ rate and timing on crop yield and $\mathrm{N}$ leaching [25], or to identify the best irrigation practices under environmental constraints [10]. Results show that the rate and timing of $\mathrm{N}$ fertilisation and the choice of irrigation strategy are key factors in nitrate leaching [14, 15, 25]. However, optimising $\mathrm{N}$ fertilisation is difficult because the $\mathrm{N}$ cycle varies in space and time [11,34]. The coeffi- cients of variation of soil nitrate concentration in agricultural fields are generally high: 10 to $133 \%$ [17], 29 to $36 \%$ [26], or 11 to $31 \%$ [19]. Without irrigation, these variations are due to heterogeneity of fertiliser application and crop residue distribution, and to percolation of water via cracks and channels. Irrigation non-uniformity is an additional source of spatial and temporal variability in the terms of the nitrogen budget. In addition to the results of Pang et al. [24, 25], the main objective of this paper is to quantify the consequences of nonuniform irrigation on nitrogen fluxes in the soil-plant system when prediction of irrigation non-uniformity for a moving gun irrigation system is linked with a crop model, and when the climate variability is taken into account over several years. We selected here a specific irrigation scheduling strategy, but many other strategies are possible and the results of the analysis would be different for each specific case.

\section{Materials and methods}

\subsection{Scenario approach}

The soil used for the simulations and the main parameters of the model are described in a companion paper [7]. Briefly, the soil was divided into several layers. The first layer $(0-0.30 \mathrm{~m})$ initially contained $50 \mathrm{~kg} \mathrm{~N} \cdot \mathrm{ha}^{-1}$, the second layer $(0.30-0.50 \mathrm{~m}) 20$, and the deepest layer $(0.50-$ $0.95 \mathrm{~m}$ ) no mineral $\mathrm{N}$. Organic $\mathrm{N}$ content in the first layer was set to $1.0 \mathrm{~g} \cdot \mathrm{kg}^{-1}$ soil. Initial inorganic $\mathrm{N}$ and water contents in the soil profile were reinitialised at the beginning of each cropping period at the same level. Crop residues were assumed to be incorporated in the soil on December 3rd (day 337). The parameterisation described above and in the companion paper [7] is referred to as the "reference". For comparison, other situations were simulated varying either in initial soil conditions at sowing, or in $\mathrm{N}$ fertilisation.

For the initial soil conditions, we simulated a situation where the soil water and nitrogen profiles depended on the preceding years. Under otherwise 
similar conditions, this allowed analysis of the consequences of the previous cropping and intercropping periods on plant growth and nitrogen fluxes. For fertiliser management, we compared an $\mathrm{N}$ application rate of $180 \mathrm{~kg} \mathrm{~N} \cdot \mathrm{ha}^{-1}$ with a rate of 280 (reference scenario). $\mathrm{N}$ application was split into $30 \mathrm{~kg}$ at sowing (day 111), and the remainder on day 172 . We also define a relative value for each term of the nitrogen budget at the field scale, defined as the dimensionless ratio of the actual spatial mean to the calculated value at a virtual location for which the target irrigation dose is assumed to be truly and uniformly applied. Consequently, relative values may be greater or smaller than 1 , and are 1 if the entire field has a similar pattern to the location receiving the target dose. The scenarios will be analysed for the 21 year simulation period.

\subsection{The NIWASAVE model}

The Niwasave model is described in a companion paper [7]. Briefly, it links an irrigation water distribution model, that calculates irrigation rates for given spatially distributed locations in the field, with the STICS model [5] that simulates the cropsoil system. The Niwasave model uses a database which numerically describes the water distribution for any given irrigation equipment (guns in our case) and for various wind directions $\left(10^{\circ}\right.$ angle step) and speeds ( $1 \mathrm{~m} \cdot \mathrm{s}^{-1}$ velocity step). Crop development and growth, yield components, water and nitrogen balance are then calculated using the STICS model. STICS is a dynamic model with a daily time step that simulates the soil-crop system within a year or for a succession of years. The soil is described as a set of horizontal layers in which water and nitrate transport and uptake are simulated, whereas production of nitrate by mineralization occurs mainly in the plough layer. Since the nitrogen balance partly depends on the carbon balance, both are calculated simultaneously. Although the model computes the carbon, water and nitrogen balances, some specific processes like ammonia volatilisation and denitrification are not included. The main variables analysed are the $\mathrm{N}$ balance components for both soil and crop, and the $\mathrm{NO}_{3}^{-}$ concentration in soil.

\section{Results}

\subsection{Climatic database}

Approximately $69 \%$ of the rain fell in the cropping period, $31 \%$ during the intercropping period (Tab. Ia). In this period however, bare soils present significant risks of drainage because rain generally exceeds maximum evapotranspiration (Tab. Ib). Mean rainfall was $623 \mathrm{~mm}$ and $265 \mathrm{~mm}$ for the cropping and intercropping period, respectively, with associated standard deviations of $197 \mathrm{~mm}$ $(\mathrm{CV}=32 \%)$ and $81 \mathrm{~mm}(\mathrm{CV}=31 \%)$. Rain and maximum evapotranspiration were in the [275-1037 $\mathrm{mm}$ ] and [636-805 $\mathrm{mm}$ ] range for the cropping period, respectively, and in the [126-382 $\mathrm{mm}]$ and $[152-223 \mathrm{~mm}$ ] range for the intercropping period, respectively. The mean value of rain minus maximum evapotranspiration was negative in the cropping period $(-91.8 \mathrm{~mm})$, and positive during the intercropping period (82.7 $\mathrm{mm}$ ), indicating a transition from conditions of water deficit to excess water. Hence, when the cropping and intercropping periods are considered separately, climatic variability remains high.

\subsection{Nitrogen balance during the cropping period}

The mean relative values over the 21 years (Tab. II) were 0.94 (varying from 0.66 to 0.99 between years) for $\mathrm{N}$ uptake, 0.98 (varying from 0.96 to 1.07 ) for mineralised $\mathrm{N}, 1.13$ (varying from 0.97 to 1.34 ) for leached $\mathrm{N}$, and 1.11 (varying from 0.77 to 1.41 ) for $\mathrm{NO}_{3}{ }^{-}$soil concentration. For $\mathrm{N}$ uptake, the mean ratio (0.94) indicates that irrigation non-uniformity (ratio $=0.93$ for irrigation) reduces $\mathrm{N}$ uptake by the crop. For under-irrigated zones or dry years (1989, for example), $\mathrm{N}$ stress probably originates from water stress. The hypothesis that limited water availability reduces $\mathrm{N}$ uptake is in agreement with the mean ratio of 0.96 
Table I. (a) Statistics of the rain distribution for the cropping and intercropping periods during the 21 years used in the simulation; (b) statistics of the (Rain-Maximal Evapotranspiration) distribution for the cropping and intercropping periods during the 21 years used in the simulation.

\begin{tabular}{lccccc}
\hline a) & Crop & $\begin{array}{c}\text { Rain (mm) } \\
\text { Intercrop }\end{array}$ & Year & Crop & Intercrop \\
\hline Min & 275 & 126 & 456 & 48 & 15 \\
Max & 1037 & 382 & 1325 & 85 & 52 \\
Median & 627 & 263 & 867 & 70 & 29 \\
Mean & 623 & 265 & 888 & 69 & 31 \\
Standard deviation & 197 & 81 & 215 & 10 & 10 \\
CV $(\%)$ & 32 & 31 & 24 & 14 & 32 \\
\hline b) & \multicolumn{2}{c}{ Rain - Maximum Evapotranspiration (mm) } \\
& \multicolumn{2}{c}{ Crop } & Intercrop & Year & \\
Min & \multicolumn{2}{c}{-424.9} & -69.9 & -385.9 & \\
Max & & 288.1 & 221.0 & 377.6 & \\
Median & -102.2 & 83.7 & -35.2 & \\
Mean & -91.8 & 82.7 & -12.9 & \\
Standard deviation & & 204.2 & 98.7 & 225.5 & \\
\hline
\end{tabular}

Table II. Statistics of relative $\mathrm{N}$ uptake, mineralised $\mathrm{N}$, and leached $\mathrm{N}$, and soil $\mathrm{NO}_{3}{ }^{-}$concentration during the 21 years (the ratio is 1 if the entire field has a similar pattern to the location receiving the target dose).

\begin{tabular}{lcccc}
\hline & Crop N uptake & Mineralised N & Leached N ${ }^{(1)}$ & Soil NO $_{3}{ }^{-}$Concentration \\
\hline Min & 0.66 & 0.96 & 0.97 & 0.77 \\
Max & 0.99 & 1.07 & 1.34 & 1.41 \\
Median & 0.94 & 0.98 & 1.09 & 1.10 \\
Mean & 0.94 & 0.98 & 1.13 & 1.11 \\
Standard deviation & 0.07 & 0.03 & 0.12 & 14 \\
CV $(\%)$ & 7.5 & 3 & 11 & 14 \\
\hline
\end{tabular}

(1) Only years for which leached $\mathrm{N}$ is greater than $10 \mathrm{~kg} \cdot \mathrm{ha}^{-1}$ are taken into account (16 years).

calculated for evapotranspiration in the same conditions [7]. For over-irrigated or wet years, higher $\mathrm{N}$ leaching during the cropping period may have reduced inorganic $\mathrm{N}$ available for crop uptake.

Relative N mineralization is close to $1(0.98)$ with low temporal variability between years $(\mathrm{CV}=$ $3 \%$ ). This may be attributed to: (i) mineralization is not very sensitive to spatial variations in water content from non-uniform irrigation; (ii) mineralization is sensitive to variations in climatic conditions (air temperature, for example) and microbial activity, factors that were regarded uniform for the whole field.

For leaching, the mean ratio exceeds 1 (1.13), and showed greater variability between years (standard deviation 0.12) than crop uptake (standard deviation 0.07), or mineralization (standard deviation 0.03). This results from the strong impact of over-irrigated zones in the field: a few locations in the field with high leaching are sufficient to 
produce a ratio exceeding 1 . These results are close to those previously obtained for drainage [7], except that the temporal variability for leaching is greater, because it combines variability in drainage and variability in the soil inorganic $\mathrm{N}$ concentration (Tab. II).

The standard deviations and coefficients of variation of $\mathrm{N}$ uptake due to spatial variation varied between 2 and $28 \mathrm{~kg} \cdot \mathrm{ha}^{-1}$, and 1 and $10 \%$ respectively, during the 21 years (Tab. III), except in one dry year (1989: $46 \mathrm{~kg} \cdot \mathrm{ha}^{-1}$ and 37\%). $\mathrm{N}$ uptake by the crop was $300 \mathrm{~kg} \cdot \mathrm{ha}^{-1}$, and variation between years was small (Fig. 1a and Tab. III). This suggests that nitrogen uptake was generally not limited by irrigation conditions, except in 1989. Spatial variability in crop $\mathrm{N}$ uptake (Fig. 2a and Tab. III) was generally low, and of the same order of magnitude between years (mean value of $19 \mathrm{~kg} \cdot \mathrm{ha}^{-1}$ ), except in 1989 when $\mathrm{N}$ uptake was directly related to low and non-uniform evapotranspiration. These results are in agreement with the spatial variability in evapotranspiration (coefficient of variation between 0.1 and $9 \%$ ), indicating that $\mathrm{N}$ uptake was correlated to crop transpiration and dry matter production (Fig. 3).

The spatial variability of $\mathrm{N}$ mineralization was low: standard deviations and coefficients of variation were in the (1-7 kg.ha- $\left.{ }^{-1}\right)$ and (1-8\%) range, respectively. Temporal effects dominated (Fig. 1b), except in overlapping zones due to successive gun movements where the wet soil favoured mineralization (Fig 2b). Mineralization rate depends on soil organic matter, clay and $\mathrm{CaCO}_{3}$ contents, $\mathrm{C} / \mathrm{N}$ ratio of crop residues and biomass activity. In the current version of the model, these characteristics are considered constant throughout the field. Air and soil temperatures are the same or similar for the entire field, and variability in air temperature between years is lower than rain variability. Only the soil's air and water content variability between individual plots in the field may contribute to spatial variability. Nevertheless, variations may occur during short periods after irrigation, but water redistribution in the soil until field capacity is reached and water uptake by roots probably lead to homogenisation of soil water content.

Standard deviations for $\mathrm{N}$ leaching, varied from 0 to $18 \mathrm{~kg} \cdot \mathrm{ha}^{-1}$. Leaching varied from 0 to $130 \mathrm{~kg} \cdot \mathrm{ha}^{-1}$, the coefficients of variation from 3 to $34 \%$. In dry years, leaching was nil or limited throughout the field, and the variability low, as expected. In wet years, leaching occurred at some specific locations or on the whole field, depending on the source of water (uniform rain or non-uniform irrigation), thus leading to various situations of leaching at field level. Temporal variations in leaching among years dominated (Fig. 1c), whereas the distribution of nitrate leaching along the transect highlighted the overlapping zones (Fig. 2c). Variations in leaching were correlated with drainage variations (Fig. 4), but spatial variability in leaching was greater, especially in wet years. Leaching becomes significant when drainage exceeds $150-180 \mathrm{~mm}$, which roughly corresponds to soil water content at field capacity, and the large variations in leaching for a given level of drainage are due to variations in nitrate concentration in the soil profile (Tab. II).

Table III. Statistics (mean, standard deviation $\sigma$, coefficient of variation CV) of N uptake, mineralised N and leached N during the cropping period for the whole field during the 21 years simulated.

\begin{tabular}{lccccccccc}
\hline & \multicolumn{3}{c}{ Crop N uptake } & \multicolumn{3}{c}{ Mineralised N } & \multicolumn{3}{c}{ Leached N } \\
& $\begin{array}{c}\text { Mean } \\
\left(\mathrm{kg} \cdot \mathrm{ha}^{-1}\right)\end{array}$ & $\sigma$ & $\begin{array}{c}\mathrm{CV} \\
(\%)\end{array}$ & $\begin{array}{c}\text { Mean } \\
\left(\mathrm{kg} \cdot \mathrm{ha}^{-1}\right)\end{array}$ & $\sigma$ & $\begin{array}{c}\text { CV } \\
(\%)\end{array}$ & \multicolumn{2}{c}{$\begin{array}{c}\text { Mean } \\
\left(\mathrm{kg} \cdot \mathrm{ha}^{-1}\right)\end{array}$} & $\begin{array}{c}\sigma \\
(\%)\end{array}$ \\
\hline Min & 124 & 2 & 1 & 93 & 1 & 1 & 0 & 0 & 0 \\
Max & 367 & 46 & 37 & 138 & 7 & 8 & 130 & 18 & 34 \\
Median & 307 & 18 & 6 & 119 & 3 & 3 & 44 & 4 & 12 \\
Mean & 300 & 19 & 7 & 117 & 3 & 3 & 51 & 7 & 14 \\
\hline
\end{tabular}



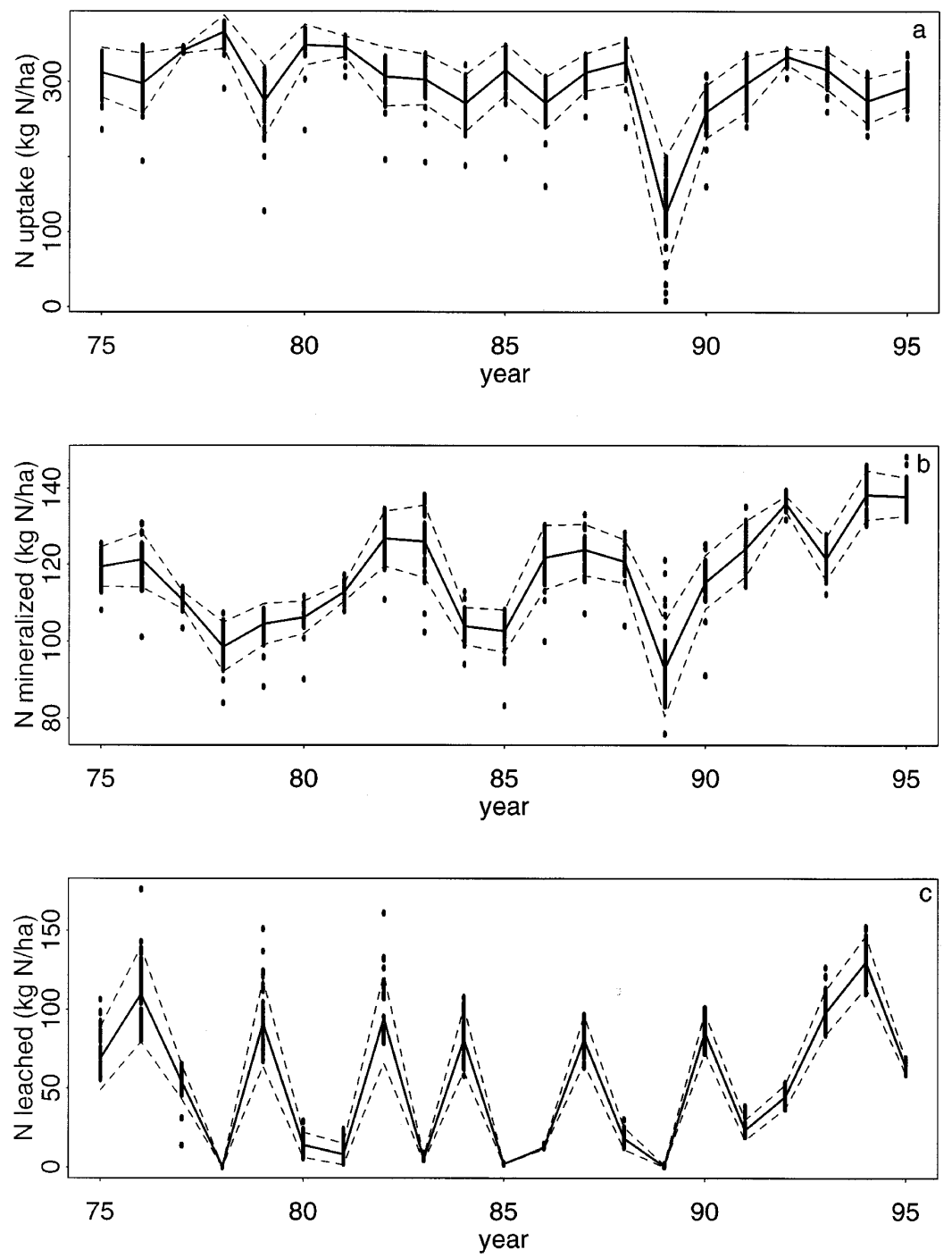

Figure 1. Simulated variations in (a) crop $\mathrm{N}$ uptake, (b) mineralised $\mathrm{N}$, and (c) leached $\mathrm{N}$ in the cropping period during the 21 years simulated. The continuous line represents the mean, the dashed lines represent the confidence interval. Each point corresponds to a $5 \mathrm{~m}$ plot located along a transect perpendicular to the direction in which the gun moves.

\subsection{Nitrogen balance during the intercropping period}

Mineral $\mathrm{N}$ in the soil at the beginning of the intercropping period (maize harvest) varied between 26 and $274 \mathrm{~kg} \cdot \mathrm{ha}^{-1}$, with a mean of $74 \mathrm{~kg} \cdot \mathrm{ha}^{-1}$ (Tab. IVb, Fig. 5a). Its spatial variability (Fig. 6a) was generally low (standard deviation varied from 0.1 to $15 \mathrm{~kg} \cdot \mathrm{ha}^{-1}$ ), except for one year (1989) in which spatial variability of crop uptake was high (standard deviation $46 \mathrm{~kg}$ ), resulting in a similar spatial variability of the residual inorganic $\mathrm{N}$ at harvest (standard deviation $45 \mathrm{~kg} \cdot \mathrm{ha}^{-1}$ ). The moderate variability in residual inorganic $\mathrm{N}$ in the soil is associated with the low heterogeneity of $\mathrm{N}$ uptake and leaching during the cropping period which reduces or eliminates soil variability, especially in over-irrigated conditions. Residual soil N at harvest decreases when drainage during the cropping period is higher (Fig. 7). High drainage levels (more than $300 \mathrm{~mm}$ ) are associated with low spatial variability of the residual $\mathrm{N}$, whereas in low 
Figure 2. Spatial distribution along a transect of (a) $\mathrm{N}$ plant uptake, (b) mineralised $\mathrm{N}$, (c) leached $\mathrm{N}$ in the cropping period during the 21 years simulated. Each line corresponds to one year, the dashed lines indicate the position in which the gun moves.
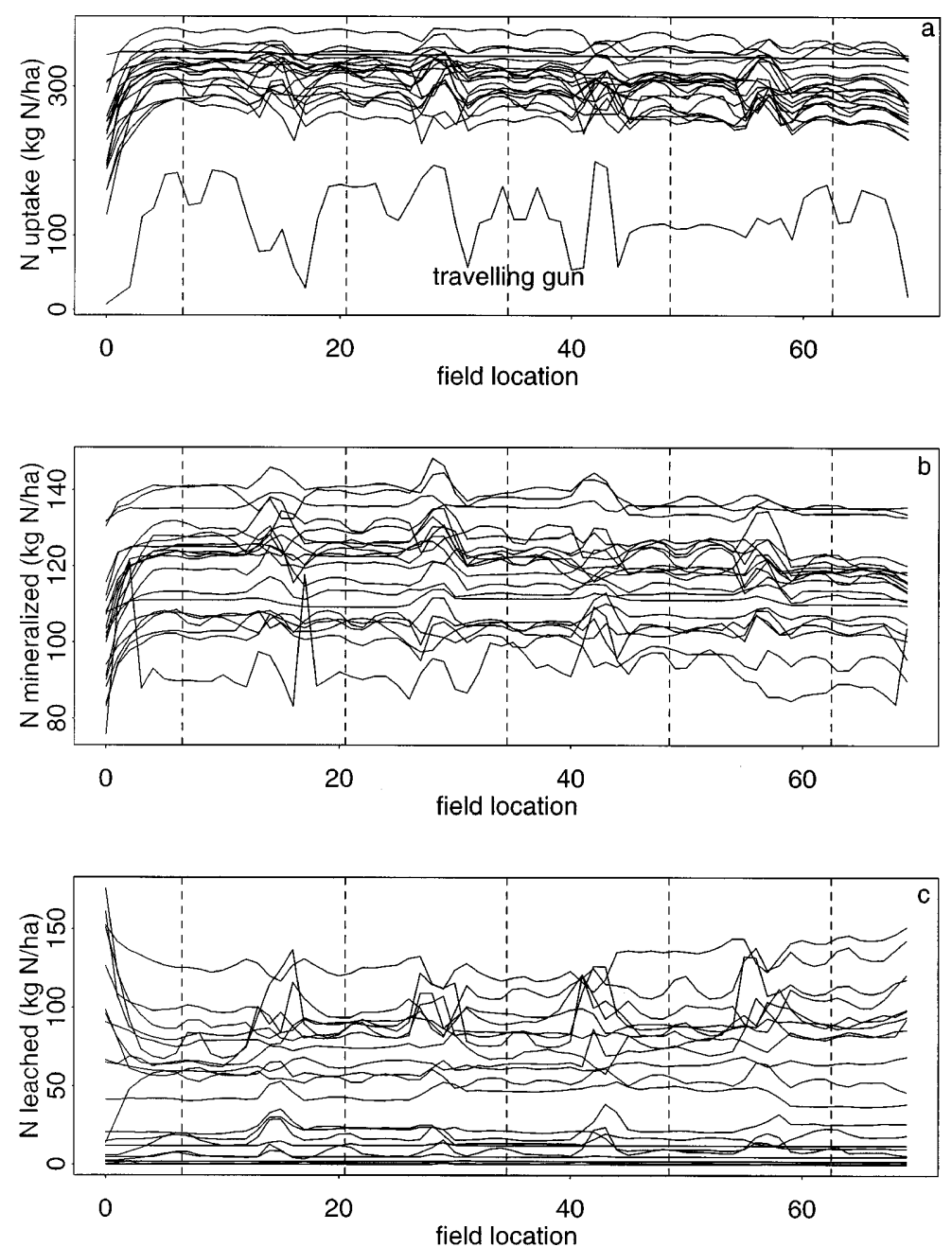

drainage situations, variability in residual $\mathrm{N}$ is higher, which is associated with spatial variability in $\mathrm{N}$ uptake.

$\mathrm{N}$ immobilisation due to decomposition of maize residues varied between 14 and $37 \mathrm{~kg} \cdot \mathrm{ha}^{-1}$ (Tab. IVa, Fig. 5b), which is expected since the maize residues have a high $\mathrm{C} / \mathrm{N}$ ratio. The simulated immobilisation values fall in the range of values measured under field conditions [18, 29], but are smaller than potential values measured in laboratory conditions, indicating that mineral $\mathrm{N}$ availability was a limiting factor [28]. Spatial variability (Fig. 6b) was generally low (standard deviation varied from 0.1 to $6 \mathrm{~kg} \cdot \mathrm{ha}^{-1}$ ). $\mathrm{N}$ mineralised from humified organic matter was small and varied between 18 and $28 \mathrm{~kg} \cdot \mathrm{ha}^{-1}$, with negligible spatial variability. The low variability in immobilisation and mineralization was due to the fact that (i) the amounts of crop residues weakly varied (the spatial coefficient of variation for yield was generally less than 13\%), (ii) no irrigation occurred in the intercropping period, thus reducing the variability in soil water content and in microbial activity, and (iii) other factors like temperature or soil texture for example were constant at the scale of the field.

Leaching ranged between 9 and $93 \mathrm{~kg} \cdot \mathrm{ha}^{-1}$ (Fig. 5c). Standard deviations and coefficients of variation varied from 0.1 to $14 \mathrm{~kg} \cdot \mathrm{ha}^{-1}$, and from 1 


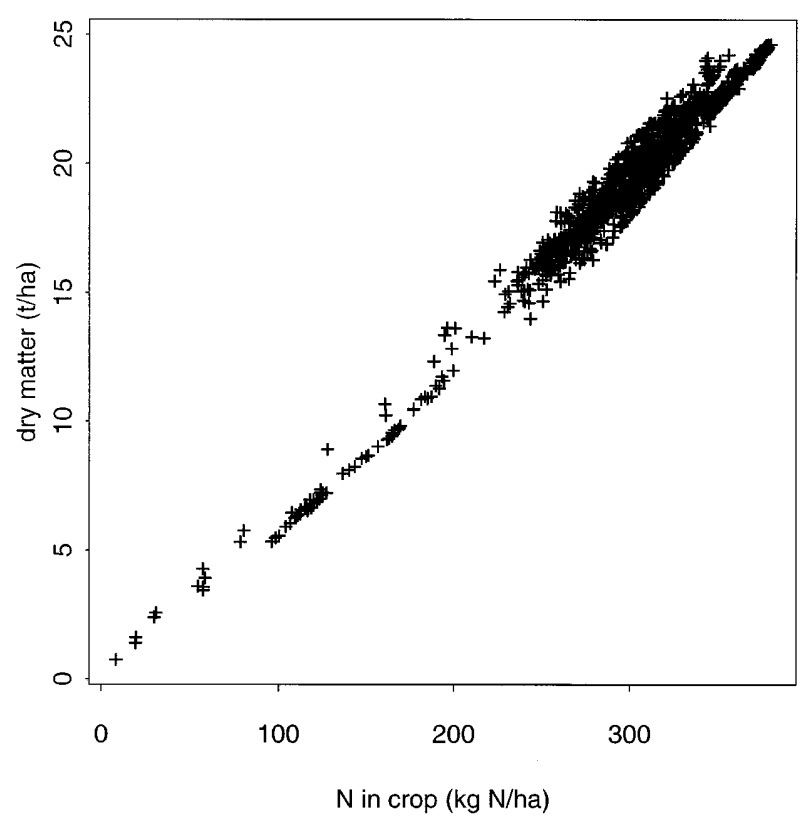

Figure 3. Relationship between dry matter and $\mathrm{N}$ uptake by maize at harvest in the cropping period during the 21 years simulated.

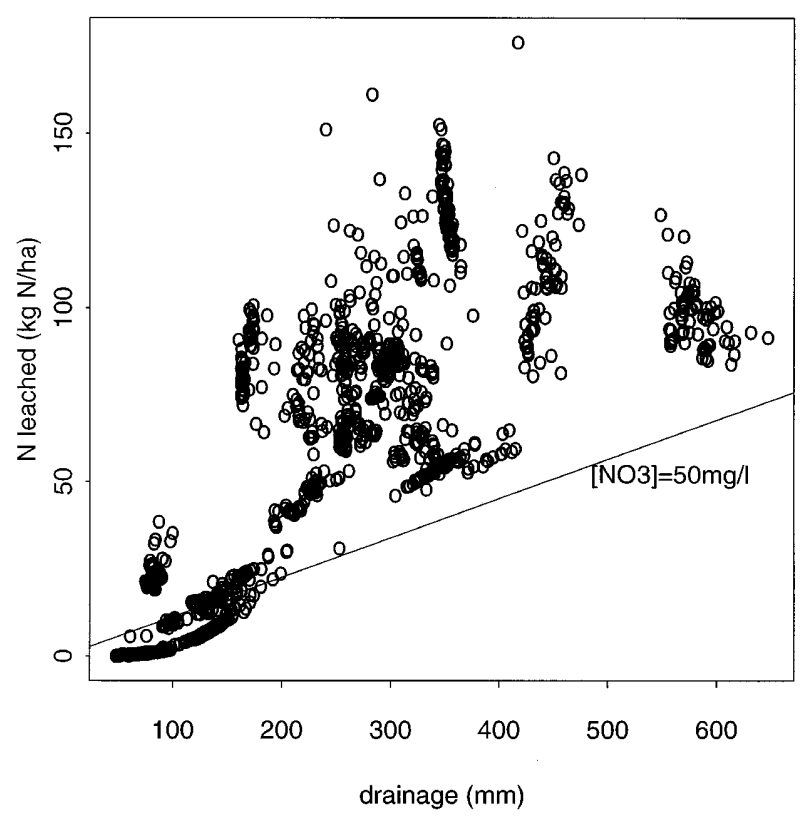

Figure 4. Relationship between leached $\mathrm{N}$ and drainage in the cropping period during the 21 years simulated.

Table IV. (a) Statistics (mean, standard deviation $\sigma$, coefficient of variation CV) of immobilised N, mineralised N, and leached $\mathrm{N}$ during the intercropping period for the whole field during the 21 years simulated; (b) statistics (mean, standard deviation $\sigma$, coefficient of variation $\mathrm{CV}$ ) of mineral $\mathrm{N}$ in soil at harvest and at sowing (next year) for the whole field during the 21 years simulated.

\begin{tabular}{|c|c|c|c|c|c|c|c|c|c|}
\hline \multirow[t]{2}{*}{ a) } & \multicolumn{3}{|c|}{$\begin{array}{l}\text { Immobilised N } \\
\text { (crop residues) }\end{array}$} & \multicolumn{3}{|c|}{$\begin{array}{l}\text { Mineralised N } \\
\text { (organic matter) }\end{array}$} & \multicolumn{3}{|c|}{ Leached N } \\
\hline & $\begin{array}{c}\text { Mean } \\
\left(\mathrm{kg} \cdot \mathrm{ha}^{-1}\right)\end{array}$ & $\sigma$ & $\begin{array}{l}\mathrm{CV} \\
(\%)\end{array}$ & $\begin{array}{c}\text { Mean } \\
\left(\mathrm{kg} \cdot \mathrm{ha}^{-1}\right)\end{array}$ & $\sigma$ & $\begin{array}{l}\mathrm{CV} \\
(\%)\end{array}$ & $\begin{array}{c}\text { Mean } \\
\left(\mathrm{kg} \cdot \mathrm{ha}^{-1}\right)\end{array}$ & $\sigma$ & $\begin{array}{l}\mathrm{CV} \\
(\%)\end{array}$ \\
\hline Min & 14 & 0.1 & 0.3 & 18 & 0.0 & 0 & 9 & 0.1 & 1 \\
\hline Max & 37 & 6 & 30 & 28 & 0.2 & 1 & 93 & 14 & 50 \\
\hline Median & 20 & 1 & 3 & 24 & 0.0 & 0 & 19 & 3 & 14 \\
\hline Mean & 23 & 1 & 5 & 24 & 0.1 & 0 & 28 & 4 & 16 \\
\hline
\end{tabular}

b)

\section{$\mathrm{N}$ storage harvest (year " $\mathrm{n}$ ")}

Mean

$\left(\mathrm{kg} \cdot \mathrm{ha}^{-1}\right)$

$\sigma \quad \mathrm{CV}$

$(\%)$

\begin{tabular}{lcccccc}
\hline Min & 26 & 0.1 & 0.4 & 15 & 0.1 & 1 \\
Max & 274 & 45 & 25 & 277 & 47 & 27 \\
Median & 62 & 8 & 9 & 52 & 6 & 5 \\
Mean & 74 & 9 & 11 & 6 & 9 \\
\hline
\end{tabular}

$\mathrm{N}$ storage sowing (year " $\mathrm{n}+1$ ")

$\begin{array}{ccc}\text { Mean } & \sigma & \mathrm{CV} \\ \left(\mathrm{kg} \cdot \mathrm{ha}^{-1}\right) & & (\%)\end{array}$

(\%) 
Figure 5. Simulated variations in (a) mineral $\mathrm{N}$ in soil at harvest, (b) immobilised $\mathrm{N}$ (the negative values indicate a decrease in mineral $\mathrm{N}$ amount in the soil), (c) leached $\mathrm{N}$ in the intercropping period, (d) mineral $\mathrm{N}$ in soil at the end of the intercropping period during the 21 years simulated.

The continuous line represents the mean, the dashed lines represent the confidence interval. Each point corresponds to a $5 \mathrm{~m}$ plot located along a transect perpendicular to the direction in which the gun moves.
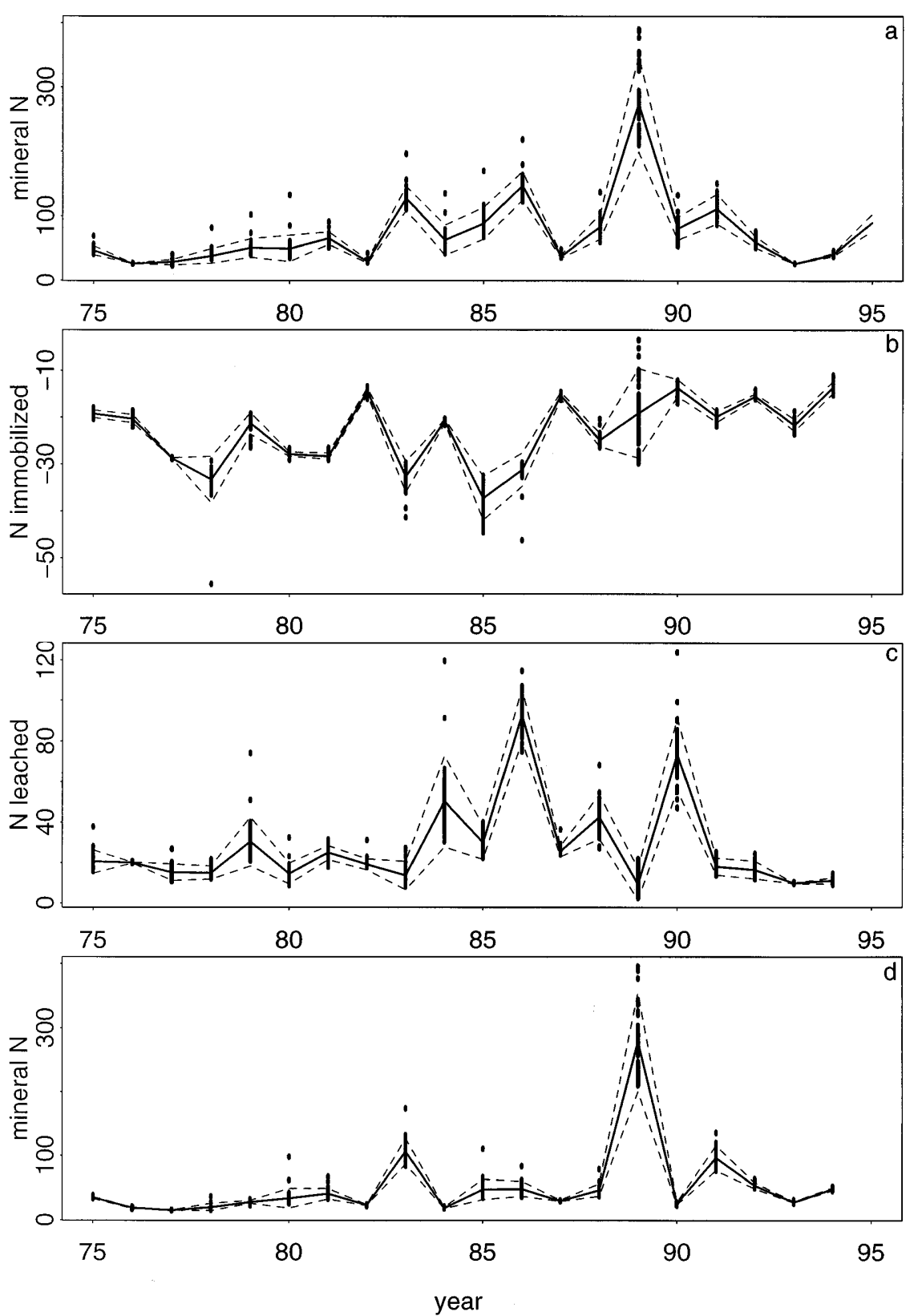

to $50 \%$ between years, respectively (Tab. IVa). N leaching depends mainly on drainage during winter (Fig. 8a) and on residual soil $\mathrm{N}$ at harvest (Fig. 8b). Each year, however, presents a specific combination of water availability and $\mathrm{N}$ distribution in the soil profile. Spatial variability in leaching (Fig. 6c) results from (i) spatial variability in residual soil $\mathrm{N}$ at harvest (Fig. 6a), (ii) N immobilisation and mineralization variability which was low (Tab. IVa), (iii) soil water content at harvest which was not uniformly distributed, and partially modified $\mathrm{N}$ fluxes, even in the absence of irrigation, and (iv) 

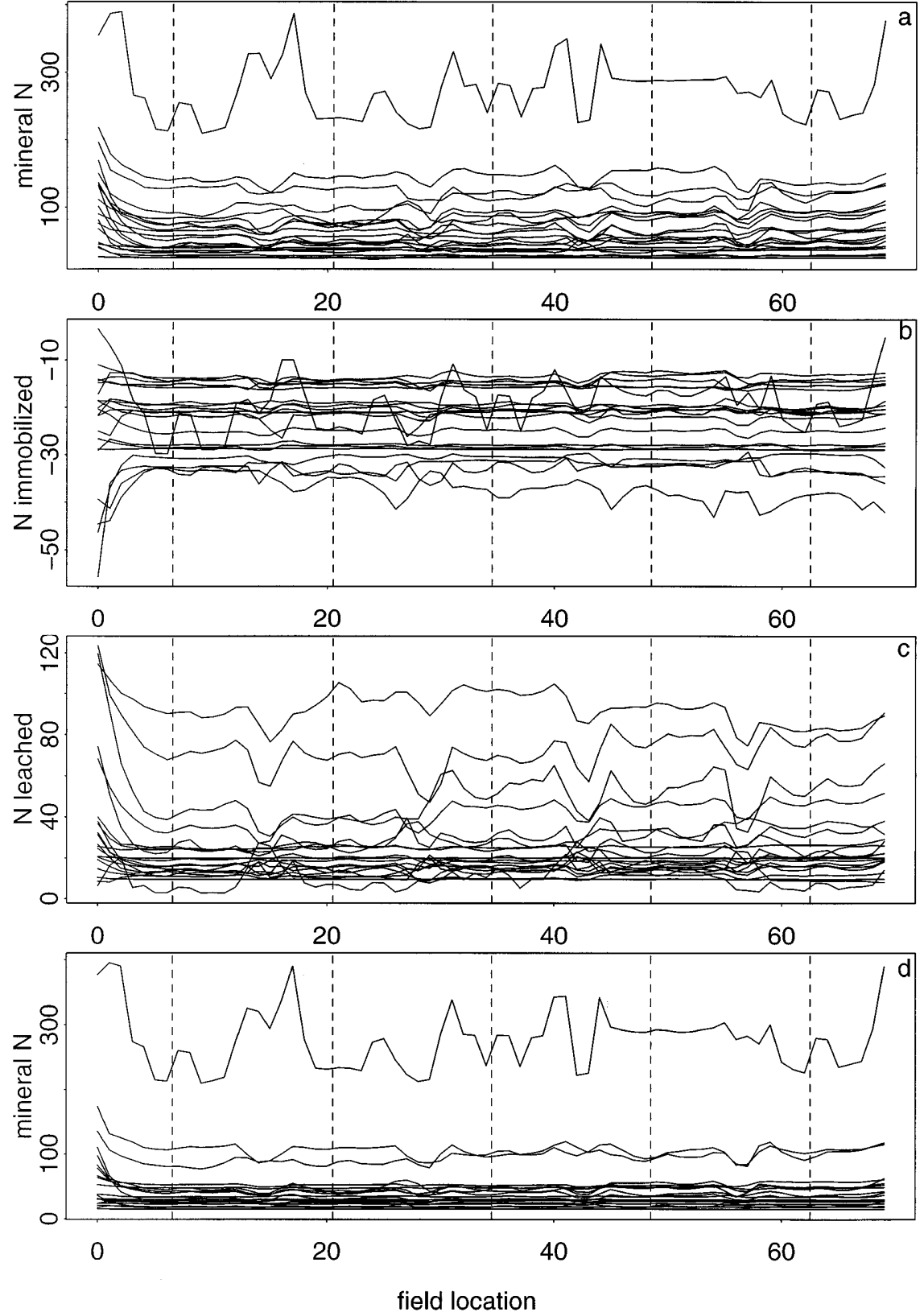

Figure 6. Spatial distribution along a transect of (a) mineral $\mathrm{N}$ in soil at harvest, (b) immobilised $\mathrm{N}$ (the negative values indicate a decrease in mineral $\mathrm{N}$ amount in the soil), (c) leached $\mathrm{N}$ in the intercropping period, (d) mineral $\mathrm{N}$ in soil at the end of the intercropping period during the 21 years simulated. Each line corresponds to one year, the dashed lines indicate the direction in which the gun moves. water drained during the intercropping period (Fig. 8a). As net $\mathrm{N}$ mineralization and $\mathrm{N}$ leaching during winter varied little among years, the spatial and temporal distribution of the soil's inorganic $\mathrm{N}$ at the beginning (Fig. 5a, Fig. 6a) and end (Fig. 5d, Fig. 6d) of the intercropping period were roughly similar. Nevertheless, leaching was markedly higher in some years $(1984,1986,1990)$, thus reducing the amount of mineral $\mathrm{N}$ at the end of the intercropping period and its spatial variability.

\subsection{Long term nitrogen balance}

In the previous sections, we simulated situations where the soil water and nitrogen profiles at 
Figure 7. Relationship between mineral $\mathrm{N}$ in soil at harvest and water drained during the cropping period for the 21 years simulated (each point corresponds to a $5 \mathrm{~m}$ plot located along a transect perpendicular to the direction in which the gun moves).

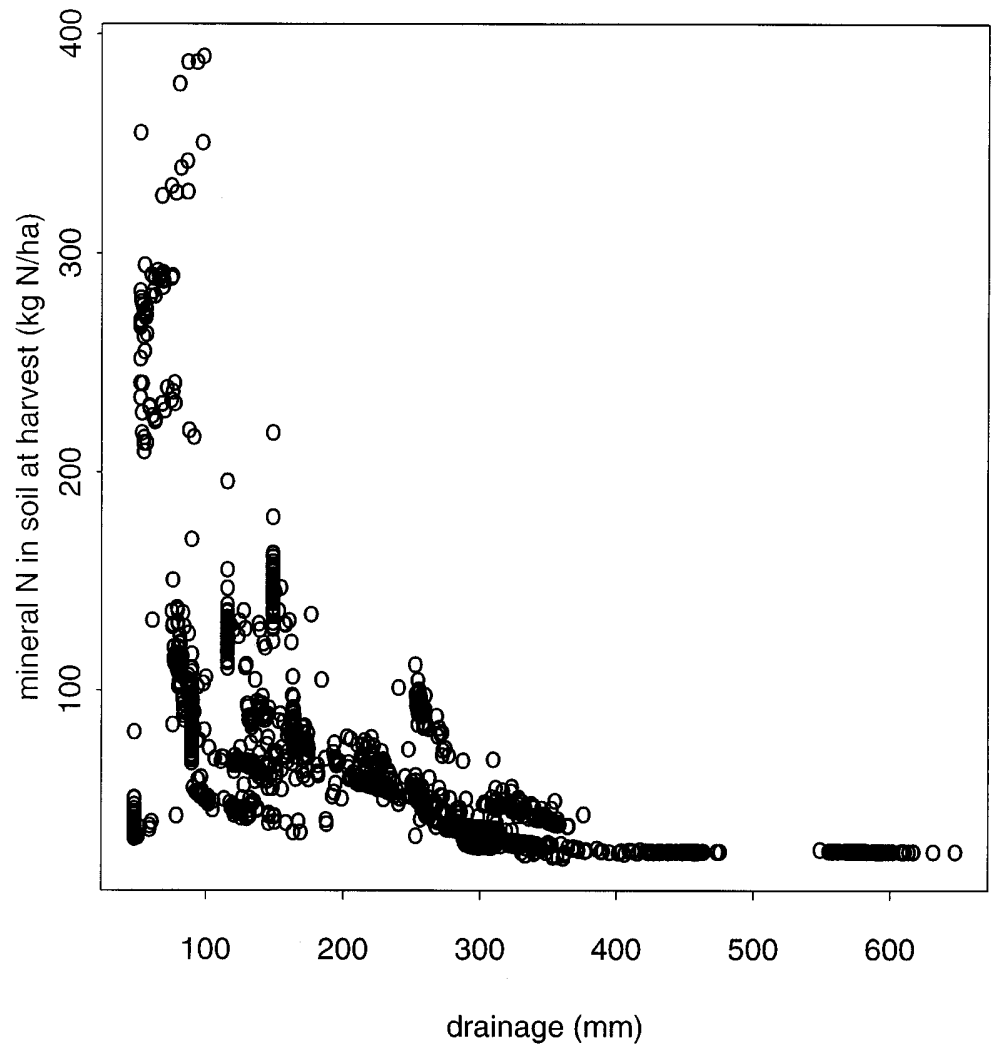

sowing did not depend on the preceding years. Thus, initial water and nitrogen profiles were reinitialised each year at the same values. As shown above however, each intercropping period can end with a variable amount of mineral $\mathrm{N}$ in the soil, with a low spatial variability, except for particular years (1989 for example). We now simulate situations where the soil water and nitrogen profiles at the start of the cropping period depend on the preceding years. Results are generally similar for the reinitialised and continuous situations (21 years, 70 locations per year), except in two years (1982 and 1991), in which a severe reduction in yield was observed for the continuous situation. In these 2 years, water stress developed in May, soon after sowing in dry soil, leading to irreversible water stress later. Leaf area index, biomass and yield were strongly reduced (Fig. 9a), leading to lower water uptake (Fig. 9b), and moderately higher drainage (Fig. 9c). Consequently, crop $\mathrm{N}$ uptake was strongly reduced in 1982 and 1991 (Fig. 10a), resulting either in higher leaching (1982, Fig. 10b), or a higher inorganic $\mathrm{N}$ content in the soil at maize harvest (1991, Fig. 10c). This situation in 1991, combined with similar $\mathrm{N}$ leaching during the intercropping period (Fig. 10d), resulted in both higher inorganic $\mathrm{N}$ in the soil at sowing for the next year, i.e. in 1992 (Fig. 10e), and higher drainage during the cropping period in 1992 (Fig. 10b).

\subsection{Optimising fertilisation}

In the reference situation, the $\mathrm{N}$ fertiliser rate was $280 \mathrm{~kg} \cdot \mathrm{ha}^{-1}$. Taking into account the inorganic $\mathrm{N}$ present at the beginning of the cropping period, and $\mathrm{N}$ mineralised during the cropping period, more than $400 \mathrm{~kg} \cdot \mathrm{ha}^{-1}$ of $\mathrm{N}$ was available for the crop which absorbed at most $300 \mathrm{~kg} \cdot \mathrm{ha}^{-1}$. Therefore, the effects of reducing $\mathrm{N}$ fertilisation to 

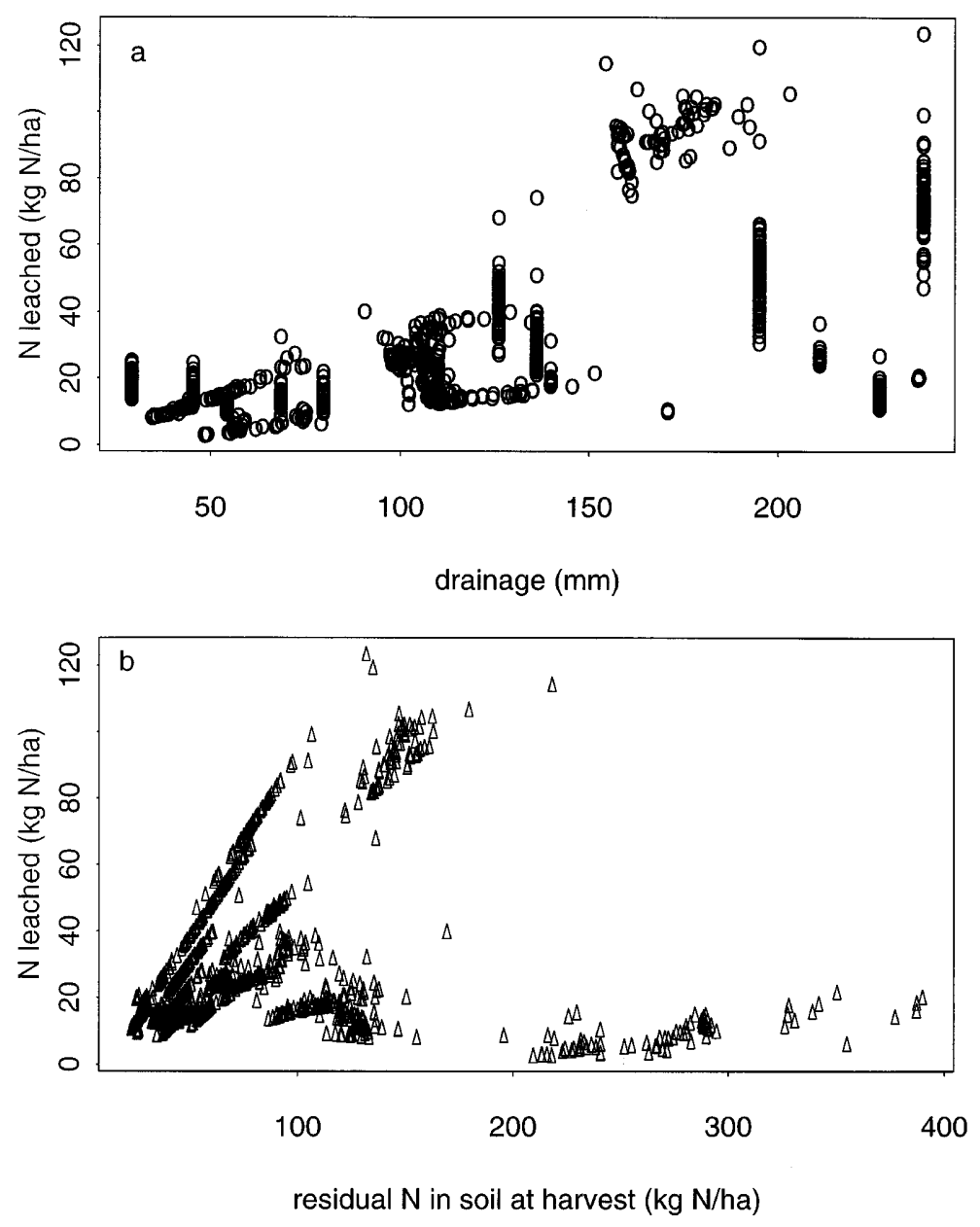

Figure 8. Relationship between (a) the leached $\mathrm{N}$ and the water drained, and (b) the leached $\mathrm{N}$ and the residual $\mathrm{N}$ in soil at harvest in the intercropping period during the 21 years simulated.

$180 \mathrm{~kg} \cdot \mathrm{ha}^{-1}$ are analysed. We first verified that the water balance components (irrigation, actual evapotranspiration, drainage) were identical for the two fertilisation rates, thus indicating that interactions between nitrogen and water were negligible. Total biomass and yield were similar for both situations (10.4 th.ha ${ }^{-1}$ yield for the 180 and $280 \mathrm{~kg} \mathrm{~N} \cdot \mathrm{ha}^{-1}$ treatments), showing that nitrogen availability did not limit plant growth even at the lower $\mathrm{N}$ rate. $\mathrm{N}$ uptake by the crop was only slightly lower at the lower fertilisation rate (Fig. 11a), except for some years when $\mathrm{N}$ uptake capacity was high, but without effecting the yield. The two treatments markedly differed in leaching (Fig. $11 \mathrm{~b}$ ), which was approximately $70 \mathrm{~kg} \cdot \mathrm{ha}^{-1}$ lower for the $180 \mathrm{~kg} \mathrm{~N} \cdot \mathrm{ha}^{-1}$. This result is consistent with the fact that significant drainage occurred each year during the cropping period. Residual soil $\mathrm{N}$ contents were correlated between the two treatments (Fig. 11c), and were smaller in the $180 \mathrm{~kg} \mathrm{~N} \cdot \mathrm{ha}^{-1}$ treatment. This correlation is explained by the similarity of $\mathrm{N}$ uptake and the reduction in both $\mathrm{N}$ input (fertilisation) and $\mathrm{N}$ output (leaching). During the intercropping period, $\mathrm{N}$ immobilisation due to decomposition of fresh residue was similar for the two treatments, as biomass did not differ. As rainfall was also the same, only small differences in $\mathrm{N}$ leaching appeared during the intercropping period. Hence, mineral $\mathrm{N}$ contents in the soil at the end of the intercropping period were correlated and not very different for the two treatments (Fig. 11d). In summary, the pattern of the $\mathrm{N}$ fluxes 
Figure 9. Comparison of simulated outputs with or without reinitialising the water and mineral $\mathrm{N}$ contents at the sowing date during the 21 years used in the simulation: (a) yield, (b) evapotranspiration, (c) drainage.
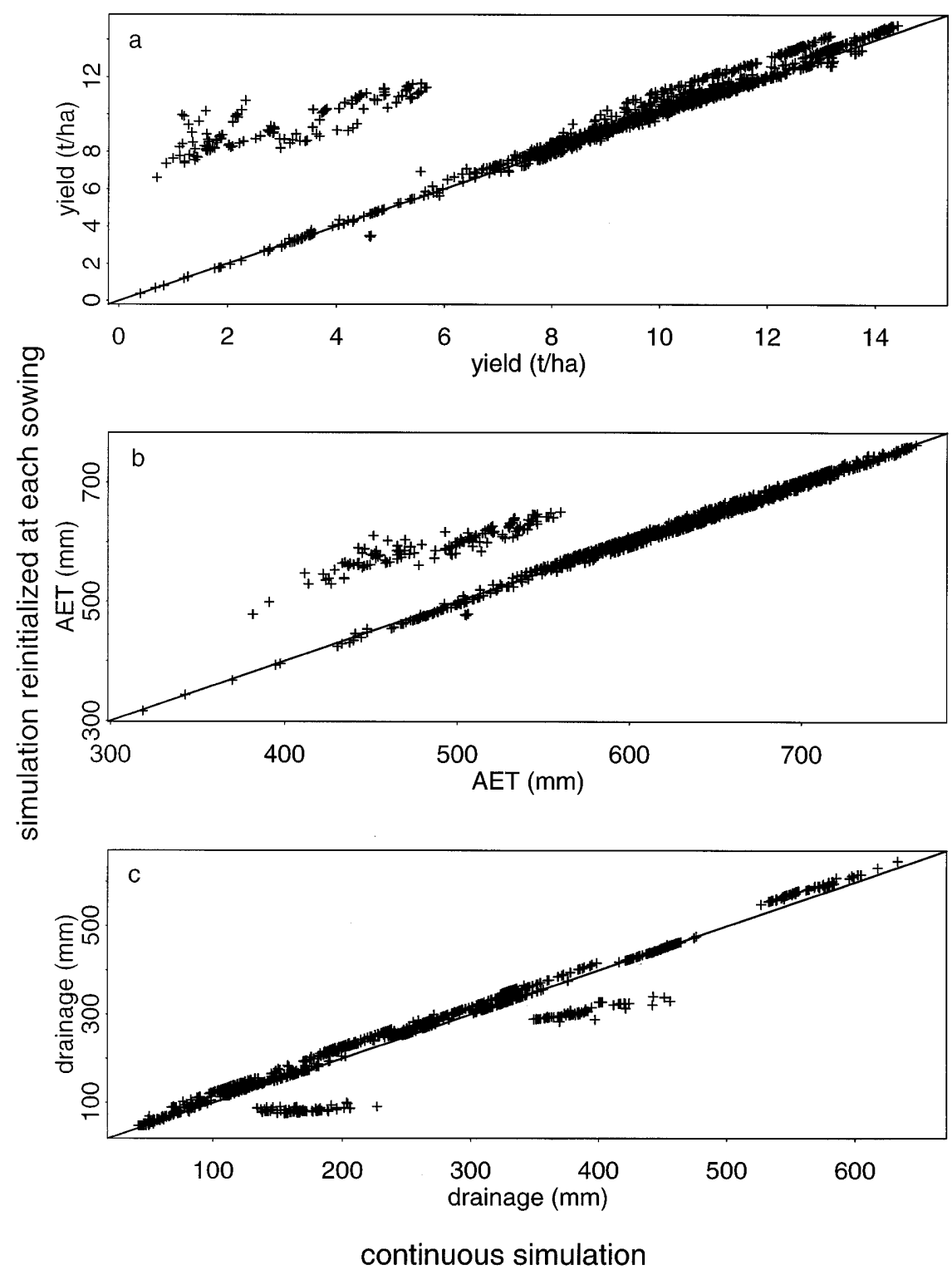

and the order of magnitude of the nitrogen balance terms were generally similar for the two treatments, except for leaching.

\section{Discussion}

Among the models simulating water flow, nutrient transport, crop uptake of water and nutrients and biological transformations of $\mathrm{N}$ in soil $[12,13$, $24,27,33]$, the Niwasave model takes into account irrigation non-uniformity and agricultural management practices at the field scale, which allows analysis of their impact on the crop and the environment. The results show that, although spatial variability of water and nitrogen fluxes and yield exists, the estimated mean for the whole field is close to the value for a field with uniform 

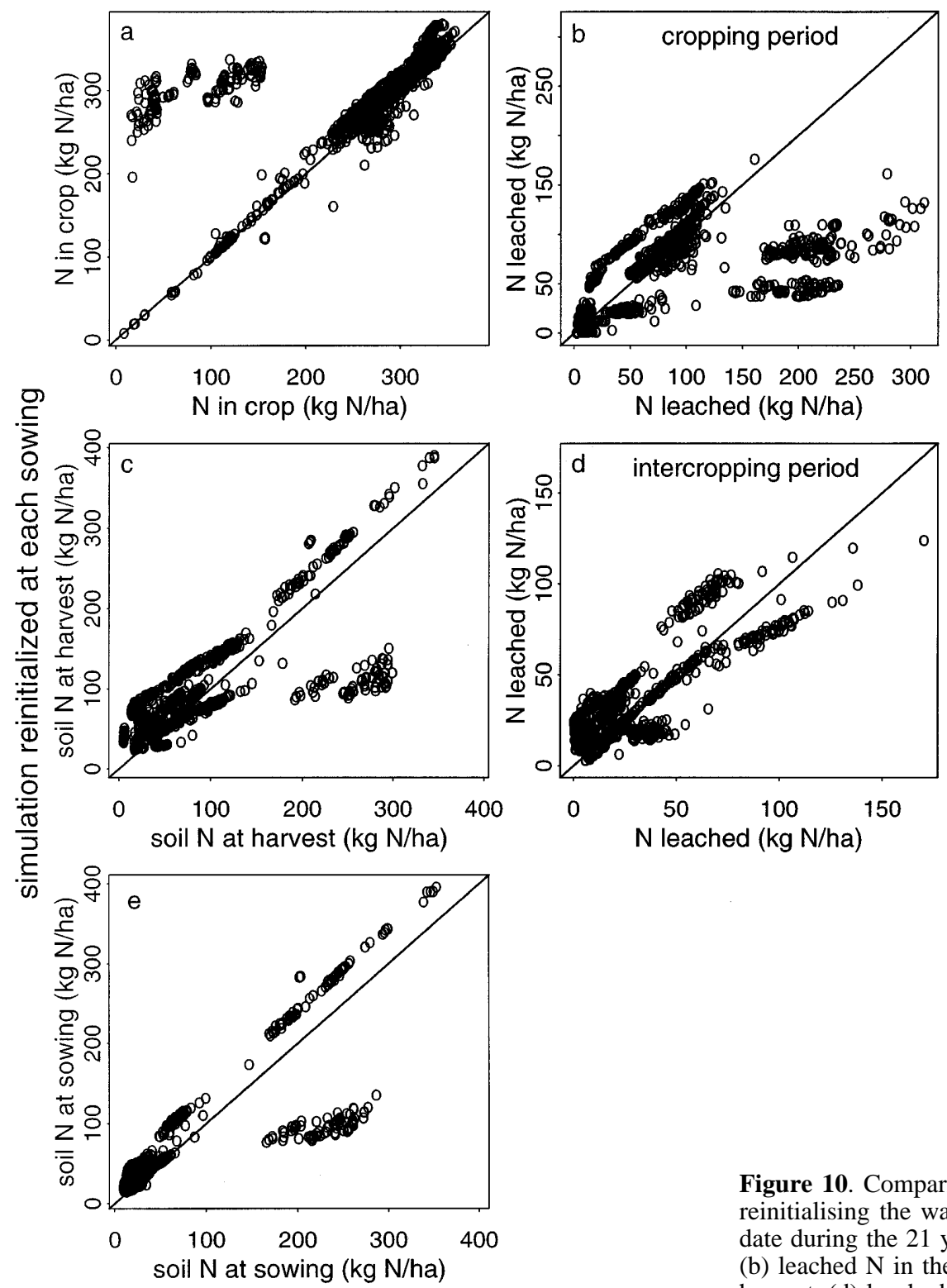

continuous simulation

Figure 10. Comparison of simulated outputs with or without reinitialising the water and mineral $\mathrm{N}$ contents at the sowing date during the 21 years used in the simulation: (a) $\mathrm{N}$ uptake, (b) leached $\mathrm{N}$ in the cropping period, (c) mineral $\mathrm{N}$ in soil at harvest, (d) leached $\mathrm{N}$ in the intercropping period, (e) mineral $\mathrm{N}$ in soil at the end of the intercropping period.

irrigation depth. Nevertheless, we selected here specific irrigation and fertilisation scheduling strategies. Many other water and nitrogen supply strategies are possible, and then the results of the analysis would be more or less different for each specific case. But our results are in agreement with those of Pang et al. [24, 25], who simulated yield

and $\mathrm{N}$ leaching using the CERES-Maize model for various combinations of irrigation depth, uniformity and $\mathrm{N}$ amount and timing of application. They showed that the results were only slightly affected by a Christiansen uniformity coefficient (CUC) of $90 \%$ compared with $100 \%$, whereas a reduction to $75 \%$ caused a reduction in yield and increase in $\mathrm{N}$ 

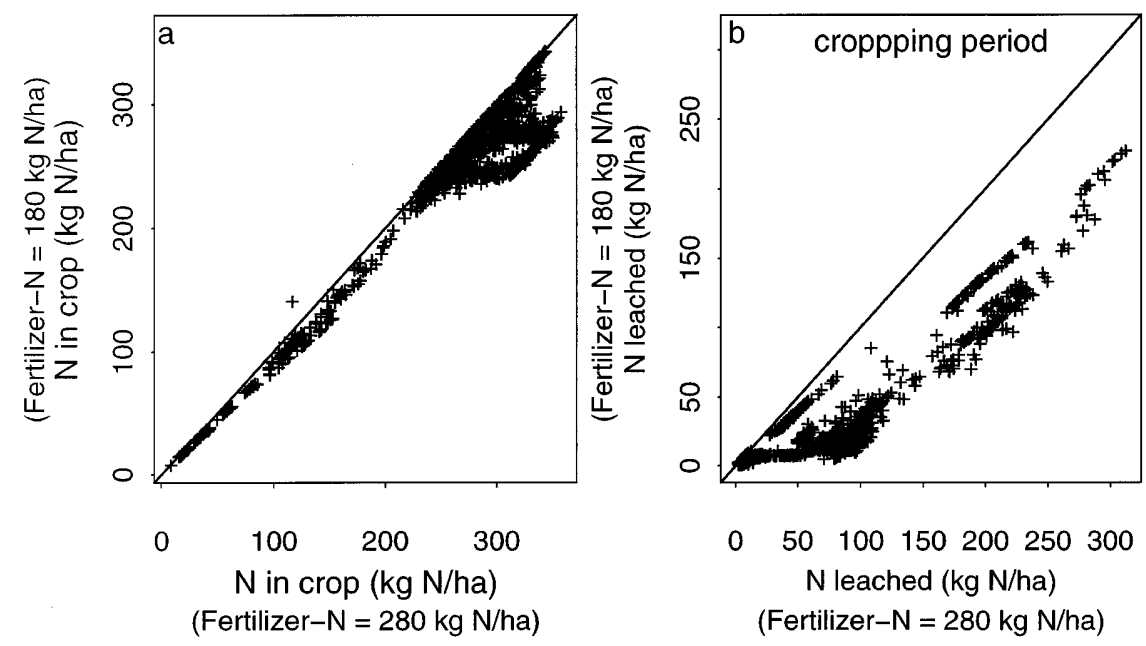

Figure 11. Comparison of simulated outputs with the high $\left(280 \mathrm{~kg} \mathrm{~N} \cdot \mathrm{ha}^{-1}\right)$ and the low $\left(180 \mathrm{~kg} \mathrm{~N} \cdot \mathrm{ha}^{-1}\right)$ fertilisation rate during the 21 years simulated: (a) $\mathrm{N}$ uptake, (b) leached $\mathrm{N}$ in the cropping period, (c) residual $\mathrm{N}$ in soil at harvest, (d) inorganic $\mathrm{N}$ at sowing.
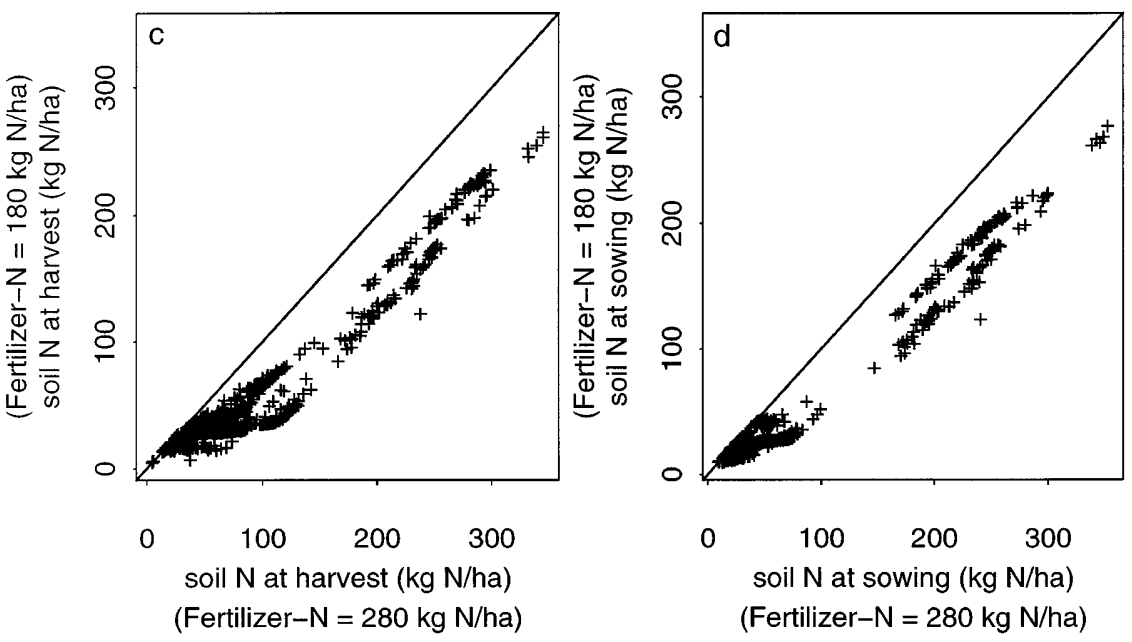

leaching compared with the uniform case. In their conditions, the maximum calculated increase in $\mathrm{N}$ leaching due to irrigation non-uniformity was about $15 \mathrm{~kg} \cdot \mathrm{ha}^{-1}$ [25].

Simulated nitrogen uptake by the crop is around $300 \mathrm{~kg} \cdot \mathrm{ha}^{-1}$, indicating no limitation for growth. Mineralization and plant uptake exhibit moderate spatial and temporal variability, whereas $\mathrm{N}$ leaching varies considerably in space and time, due to both irrigation non-uniformity and inorganic nitrogen distribution in the field, which depends on several processes involved in the nitrogen cycle.
Third, during the intercropping period, $\mathrm{N}$ mineralization and immobilisation associated with decomposition of maize residues exhibit a low spatial and temporal variability, because of low variability in biomass production. Residual mineral $\mathrm{N}$ in the soil at harvest depends on $\mathrm{N}$ uptake and leaching during the cropping period. The spatial variability in residual $\mathrm{N}$ is in most cases small, because leaching during the cropping period partly eliminates the spatial variability resulting from spatially heterogeneous $\mathrm{N}$ uptake. Leached $\mathrm{N}$ during intercropping depends on residual $\mathrm{N}$ at harvest 
and precipitation of surplus in winter, and shows large variations among years. Leaching significantly differs between high and low fertilisation treatments. This conclusion is probably valid for most irrigated or over-irrigated conditions where drainage and leaching generally occur. Finally, the analysis comparing the reinitialised or continuous situations indicates that the two situations are generally similar, except in particular cases where water or $\mathrm{N}$ stress starts before irrigation.

It may therefore be concluded that the Niwasave model provides a realistic description of irrigation distribution, crop development and growth, and $\mathrm{N}$ cycle. However, some points were disregarded. First, most of the limitations that were pointed out in modelling the consequences of irrigation nonuniformity [7] also hold for nitrogen. Briefly, (i) we did not take into account microscale plant and root heterogeneity and assumed a homogeneous lateral expanse of the root system; (ii) we assumed that the soil was spatially uniform, while variability in soil hydraulic properties has been pointed out to be in some cases responsible for yield variability [9]. Second, spatial variability in several processes of the nitrogen cycle was disregarded, although non-uniformity of fertiliser application, microbiological activity involved in $\mathrm{N}$ mineralization and organic matter distribution in soil can explain the spatial distribution of $\mathrm{N}[8,30]$. Indeed, various spatial structures of nitrate distribution have been observed at the field scale without irrigation $[3,4$, 36]. Third, different irrigation and fertilisation strategies were not, or only roughly, taken into account or compared. It was shown, however, that irrigation management or fertilisation timing had a significant effect on $\mathrm{N}$ leaching $[10,14,15,24$, 25]. Comparing three irrigation strategies (a current strategy based on the occurrence of rainfall, a strategy based on simplified soil water balance, and a strategy based on tensiometer readings), Leenhardt et al. [15] showed that strategy 1 generated a soil water content favourable to denitrification and nitrate leaching, and less favourable to mineralization and nitrification thus reducing the $\mathrm{N}$ plant uptake. Strategy 3 minimised the nitrogen stress but increased the water stress, whereas strategy 2 had an intermediate position. Thus, more varied situations should probably be simulated to arrive at general conclusions on the effects of irrigation non-uniformity on water and nitrogen budgets, and crop yield.

Our results also indicate that irrigation non-uniformity leads to specific spatial structures for water content or $\mathrm{N}$ concentration at the field scale. These spatial distributions may be periodic, depending on irrigation management, but are certainly spatially correlated in many cases [22, 32]. Consequently, adequate sampling strategies for water content or $\mathrm{N}$ analysis are required to improve $\mathrm{N}$ fertiliser management under irrigated conditions [31, 35]. Moreover, the spatial variability in $\mathrm{NO}_{3}^{-}-\mathrm{N}$ concentration caused by irrigation non-uniformity may be time-dependent as has been shown at the field scale [6]. From a theoretical point of view, regular sampling was shown to be more efficient than purely random sampling when a spatial structure exists, and the efficiency of the regular grid sampling strategy increases with spatial correlation. Consequently, regular sampling strategies are probably more adequate in non-uniformly irrigated fields.

\section{Conclusions}

Numerical experiments and modelling are useful alternatives to experimental approaches to compare different irrigation and fertilisation management schemes over long periods, and to take into account spatial variability in the soil-plant-atmosphere system. Experimental approaches cannot consider all conditions of soil water, soil fertility and crop growth induced by the diversity of soil, climatic conditions, and agricultural practices. Because soil water, $\mathrm{N}$ availability and crop growth strongly interact, it is necessary to combine several driving variables into models to predict agricultural management consequences in terms of yield and environmental quality. Absolute values of simulation results must always be considered with caution, even after validation, because conditions outside the experimental validation domain may be encountered. Nevertheless, comparisons of 
different simulated agricultural practices may generally be regarded with confidence. Results of this study indicated that both temporal and spatial variability exist. As a consequence of the spatial variability in water and nitrogen fluxes, it is difficult under non-uniform irrigation, to manage either water or $\mathrm{N}$ application to achieve high yields without $\mathrm{N}$ leaching or water and nitrogen stress. Farmers commonly apply excess $\mathrm{N}$ as an insurance against deficiency. In agricultural practice, irrigation is probably less uniform than under experimental conditions, and more $\mathrm{N}$ fertiliser may have to be applied to attain the same yield. Consequently, it remains essential to optimise both mean irrigation depth, and the amount and timing of fertilisation. However, the long-term effects of the spatial and temporal variability in water and nitrogen balances at field level must be taken into account to properly combine the short term agricultural objectives and the long term environmental constraints.

Acknowledgements: The research received financial support from EC (Contract Fair-CT95- 88). We are also indebted to C. Young of the Translation Service at INRA for revising the manuscript.

\section{References}

[1] Amali S., Rolston D.E., Fulton A.E., Hanson B.R., Phene C.J., Oster J.D., Soil water variability under subsurface drip and furrow irrigation, Irrig. Sci. 17 (1997) 151-155.

[2] Ben-Asher J., Ayars J.E., Deep seepage under nonuniform sprinkler irrigation. II. Field data, J. Irrig. Drainage Eng. 116 (1990) 363-373.

[3] Bottcher J., Strebel O., Spatial variability of groundwater solute concentrations at the water table under arable land and coniferous forest. Part 2: Field data for arable land and statistical analysis, Z. Pflanzenernähr. Bodenkd. 151 (1988) 191-195.

[4] Bramley R.G.V., White R.E., An analysis of variability in the activity of nitrifiers in a soil under pasture. I. Spatially dependent variability and optimum sampling strategy, Aust. J. Soil Sci. 29 (1991) 95-108.

[5] Brisson N., Mary B., Ripoche D., Jeuffroy M.H., Ruget F., Nicoullaud B., Gate P., Devienne-Barret F., Antonioletti R., Durr C., Richard G., Beaudoin N.,
Recous S., Tayot X., Plenet D., Cellier P., Machet J.M., Meynard J.M., Delécolle R., STICS: a generic model for the simulation of crops and their water and nitrogen balances. I. Theory and parameterisation applied to wheat and corn, Agronomie 18 (1998) 311-346.

[6] Bruckler L., de Cockborne A.M., Renault P., Claudot B., Spatial and temporal variability of nitrate in irrigated salad crops, Irrig. Sci. 17 (1997) 53-61.

[7] Bruckler L., Lafolie F., Ruy S., Granier J., Baudequin D., Modelling the agricultural and environmental consequences of nonuniform irrigation for a maize crop. 1. Water budget and yield, Agronomie 20 (2000) 609-624.

[8] Christensen S., Simkins S., Tiedje J.M., Spatial variation in denitrification: dependency of activity centers on the soil environment, Soil Sci. Soc. Am. J. 54 (1990) 1608-1613.

[9] Dagan G., Bresler E., Variability of yield of an irrigated crop and its causes. 3. Numerical simulation and field results, Water Resour. Res. 24 (1988) 395-401.

[10] Epperson J.E., Hook J.E., Mustafa Y.R., Dynamic programming for improving irrigation scheduling strategies of maize, Agric. Syst. 42 (1993) 85-101.

[11] Grundmann G.L., Rolston D.E., Kachanoski R.G., Field soil properties influencing the variability of denitrification gas fluxes, Soil Sci. Soc. Am. J. 52 (1988) 1351-1355.

[12] Lafolie F., Modelling water flow, nitrogen transport and root uptake including physical non-equilibrium and optimization of the root water potential, Fertil. Res. 27 (1991) 215-231.

[13] Lafolie F., Bruckler L., de Cockborne A.M., Laboucarié C., Modelling the water transport and nitrogen dynamics in irrigated salad crops, Irrig. Sci. 17 (1997) 95-104.

[14] Leenhardt D., Lafolie F., Bruckler L., Evaluating irrigation strategies for lettuce by simulation: 1. Water flow simulations, Eur. J. Agron. 8 (1998) 249-265.

[15] Leenhardt D., Lafolie F., Bruckler L., de Cockborne A.M., Evaluating irrigation strategies for lettuce by simulation: 2. Nitrogen Budget, Eur. J. Agron. 8 (1998) 267-282.

[16] Letey J., Vaux H.J. Jr., Feinerman E., Optimum crop water application as affected by uniformity of water infiltration, Agron. J. 76 (1984) 435-441. 
[17] Lockman R.B., Storer D.A., Soil nitrate and ammonium variation with area and date sampled, Commun. Soil Sci. Plant Anal. 21 (1990) 2219-2226.

[18] Mary B., Recous S., Darwis D., Robin D., Interactions between decomposition of plant residues and nitrogen cycling in soil, Plant and Soil 181 (1996) $71-82$.

[19] Mary B., Beaudoin N., Justes E., Machet J.M., Calculation of nitrogen mineralization and leaching in fallow soil using a simple dynamic model, Eur. J. Soil Sci. 4 (1999) in press.

[20] Mateos L., Mantovani E.C., Villalobos F.J., Cotton response to non-uniformity of conventional sprinkler irrigation, Irrig. Sci. 17 (1997) 47-52.

[21] Mateos L., Assessing whole-field uniformity of stationary sprinkler irrigation systems, Irrig. Sci. 18 (1998) 73-81.

[22] Munoz-Pardo J., Ruelle P., Vauclin M., Spatial variability of an agricultural field: geostatistical analysis of soil texture, soil moisture and yield components of two rainfed crops, Catena 17 (1990) 369-381.

[23] Musharrafieh G.R., Peralta R.C., Dudley L.M., Hanks R.J., Optimising irrigation management for pollution control and sustainable crop yield, Water Resour. Res. 31 (1995) 1077-1086.

[24] Pang X.P., Letey J., Wu L., Yield and nitrogen uptake prediction by CERES-Maize model under semiarid conditions, Soil Sci. Soc. Am. J. 61 (1997) 254-256.

[25] Pang X.P., Letey J., Wu L., Irrigation quantity and uniformity and nitrogen effects on crop yield and nitrogen leaching, Soil Sci. Soc. Am. J. 61 (1997) 257-261.

[26] Pettygrove G.S., Jiayou D., Williams J.F., Wick C., Hafez A.A.B., De Boer G., Variability of several forms of soil nitrogen in two rice fields, Commun. Soil Sci. Plant Anal. 21 (1990) 1843-1855.
[27] Rao N.H., Rees D.H., Irrigation scheduling of rice with a crop growth simulation model, Agric. Syst. 39 (1992) 115-132.

[28] Recous S., Robin D., Darwis D., Mary B., Soil inorganic N availability: effect on maize residue decomposition, Soil Biol. Biochem. 27 (1995) 1529-1538.

[29] Recous S., Aita C., Mary B., In situ changes in gross $\mathrm{N}$ transformations in bare soil after addition of straw, Soil Biol. Biochem. 31 (1999) 119-133.

[30] Robertson G.P., Huston M.A., Evans F.C., Tiedje J.M., Spatial variability in a successional plant community: Patterns of nitrogen availability, Ecology 69 (1988) 1517-1524.

[31] Russo D., Design of an optimal sampling network for estimating the variogram, Soil Sci. Soc. Am. J. 48 (1984) 708-716.

[32] Tabor J.A., Warrick A.W., Meyers D.E., Pennington D.A., Spatial variability of nitrate in irrigated cotton: II. Soil nitrate and correlated variables, Soil Sci. Soc. Am. J. 49 (1985) 390-394.

[33] Tanji K.K., Broadbent F.E., Mehran M., Fried M., An extended version of a conceptual model for evaluating annual nitrogen leaching losses from cropland, J. Environ. Qual. 8 (1979) 114-120.

[34] Van Meirvenne M., Hofman G. Spatial variability of soil nitrate nitrogen under potatoes and its change during winter, Plant and Soil 120 (1989) 103-110.

[35] Warrick A.W., Myers D.E., Optimization of sampling locations for variogram calculations, Water Resour. Res. 23 (1987) 496-500.

[36] White R.E., Haigh R.A., Macduff J.H., Frequency distribution and spatially dependent variability of ammonium and nitrate concentrations in soil under grazed and ungrazed grassland, Fertil. Res. 11 (1987) 193-208. 